\title{
Insect infestation of a botanicals warehouse in north-central Florida ${ }^{\text {ts }}$
}

\author{
Richard T. Arbogast ${ }^{\mathrm{a}, *}$, Paul E. Kendra ${ }^{\mathrm{a}}$, Richard W. Mankin ${ }^{\mathrm{a}}$, \\ Richard C. McDonald ${ }^{\mathrm{b}}$ \\ ${ }^{a}$ Center for Medical, Agricultural and Veterinary Entomology, ARS, USDA, P.O. Box 14565, Gainesville, \\ FL 32604, USA \\ ${ }^{\mathrm{b}}$ Symbiont Biological Pest Management, 194 Shull's Hollar, Sugar Grove, NC 28679, USA
}

Accepted 1 August 2001

\begin{abstract}
The insect populations of a botanicals warehouse in north-central Florida were studied to gain a better understanding of insect problems associated with stored botanicals and to identify measures that could be taken to mitigate the problems. The warehouse contained either dried saw palmetto berries, Serenoa repens (Bartram) Small, or dried passion-flower (maypop) vines, Passiflora incarnata (L.), depending on the season. Insect populations were monitored intermittently for one year using arrays of moth and beetle traps. Capture rate, relative abundance, and spatial distribution of different species were examined over time. The six most abundant species in order of abundance were: Cadra cautella (Walker), Lasioderma serricorne (F.), Oryzaephilus mercator (Fauvel), Typhaea stercorea (L.), Plodia interpunctella (Hübner), and Tribolium castaneum (Herbst). All of these appear capable of infesting saw palmetto, but the major pests were $C$. cautella and L. serricorne. Oryzaephilus mercator and P. interpunctella were also important, but T. castaneum and T. stercorea were minor. Passion-flower was a less suitable host than saw palmetto for all of the species except $T$. stercorea. Nevertheless, all of the six species infesting saw palmetto except $O$. mercator were captured in numbers sufficient to indicate that they were also capable of infesting passionflower. Lasioderma serricorne was the major pest. Spatial analysis of trap captures revealed that the insect distributions changed as different botanicals were brought in, removed, or redistributed in the storage area. Potential measures to mitigate insect problems in stored botanicals are discussed, including spatial targeting of insect control and sanitation efforts. Published by Elsevier Science Ltd.
\end{abstract}

Keywords: Botanicals; Herbs; Saw palmetto; Passion-flower; Stored-product insects

\footnotetext{
${ }^{25}$ This article reports the results of research only. The use of proprietary names is for the information and convenience of the reader. Such use does not constitute official endorsement or approval by USDA or ARS of any product or service to the exclusion of others that may be suitable.

*Corresponding author. Fax: +1-352-374-5874.

E-mail address: tarbogast@gainesville.usda.ufl.edu (R.T. Arbogast).
} 


\section{Introduction}

Botanicals are crude vegetable medicinals consisting of roots, leaves, bark, or other plant materials that are sometimes used directly, but are generally refined and processed to produce pharmaceuticals and herbal supplements. Familiar examples include ginseng, gingko, St. John's wort, and saw palmetto. The popularity and use of herbal supplements has grown substantially in recent years, and the economic value of botanicals used annually in their production is estimated conservatively at \$300-500 million (Michael McGuffin, American Herbal Products Association, personal communication). Medicinal plants may be grown and harvested as cultivated crops or gathered from their natural habitats. In either case, harvested plant materials are dried and stored for various periods of time before processing. During storage they are subject to damage and contamination by stored-product insects and mites, and infestations have been reported from various parts of the world (Kamel, 1958; Chmielewski and Golebiowska, 1971; Weidner, 1973; El-Halfawy, 1977; Tawfik et al., 1985; Basak, 1991; Li et al., 1998; Kalinovic and Rozman, 2000).

In the spring of 1998, a heavy insect infestation of stored saw palmetto berries, Serenoa repens (Bartram) Small, in a warehouse at Mascotte in north-central Florida provided an opportunity to study infestation of stored botanicals. The warehouse was used alternately for storage of saw palmetto and passion-flower (maypop), Passiflora incarnata (L.), depending on the season. Saw palmetto occurs in the southeastern coastal plain of the United States from South Carolina to Mississippi, where it is a common element of pine flatwoods, mesic hammocks, prairies, and scrubs (Bennett and Hicklin, 1998). An extract of the berries, or the ground berries themselves, are claimed to be useful in maintaining prostate and urinary tract well-being, and are sold for this purpose as a dietary supplement. The berries are harvested by hand from their natural habitats during late summer and fall. They are dried to about $10 \%$ moisture content (wet weight), bagged in burlap and stored, pending shipment to end processors in Europe and the US.

Passiflora incarnata grows wild in most of the southeastern US, typically in sunny, disturbed sites with well-drained soil, including roadsides, agricultural fields, and early successional habitats (McGuire, 1999). The entire above-ground plant (vine), including stems, leaves, flowers, and fruit, is harvested by hand in the spring from fields, citrus groves and other habitats where it grows wild. Harvesting is done by independent collectors, who deliver and sell fresh vines to the warehouse as they are collected. The vines are dried, chopped, and dried again to about $10-12 \%$ moisture content, then bagged in burlap and stored until they are shipped to processors. The plant provides a mild sedative or analgesic and is used as an ingredient in many commercial products, including herbal tea and herbal shampoo.

When we first examined the Mascotte warehouse, in April 1998, it contained the last of the 1997 saw palmetto crop, as well as berries a year older that had been purchased from another supplier. A customer in Europe had complained that berries shipped from the warehouse had arrived infested with insects, and the older berries were suspected as the source of infestation. The present paper describes this infestation and later infestations of passion-flower and saw palmetto that occurred in the warehouse over the course of a year. The purpose of the study was to gain a better understanding of insect problems associated with stored botanicals and to identify measures that could be taken to mitigate the problems. 


\section{Materials and methods}

\subsection{The warehouse and its contents}

The Mascotte facility was a modern steel structure, about $15 \mathrm{~m}$ wide by $60 \mathrm{~m}$ long, with a concrete floor (Fig. 1). About half the facility was enclosed warehouse space $(15.2 \mathrm{~m} \times$ $30.5 \mathrm{~m} \times 4.5 \mathrm{~m}$ high at the side walls). The remainder had open sides and served as a loading dock, equipment shed, and processing area. A bank of propane-fired batch dryers lined the west side of the dock and opened onto it. Machinery for cleaning was located near the south end of the dock, and debris from the cleaning operation was discharged through chutes on the west side. The debris was collected and spread on the ground around the facility or given to nursery and landscape companies to be used as mulch. Debris swept from the dryers was disposed of in the same manner.

Plywood sheets had been attached to the steel frame inside the warehouse to protect the siding from damage by forklifts. These sheets covered the walls from the floor to a height of $2.4 \mathrm{~m}$, creating a dead space in which vegetable debris accumulated. The warehouse was cleaned
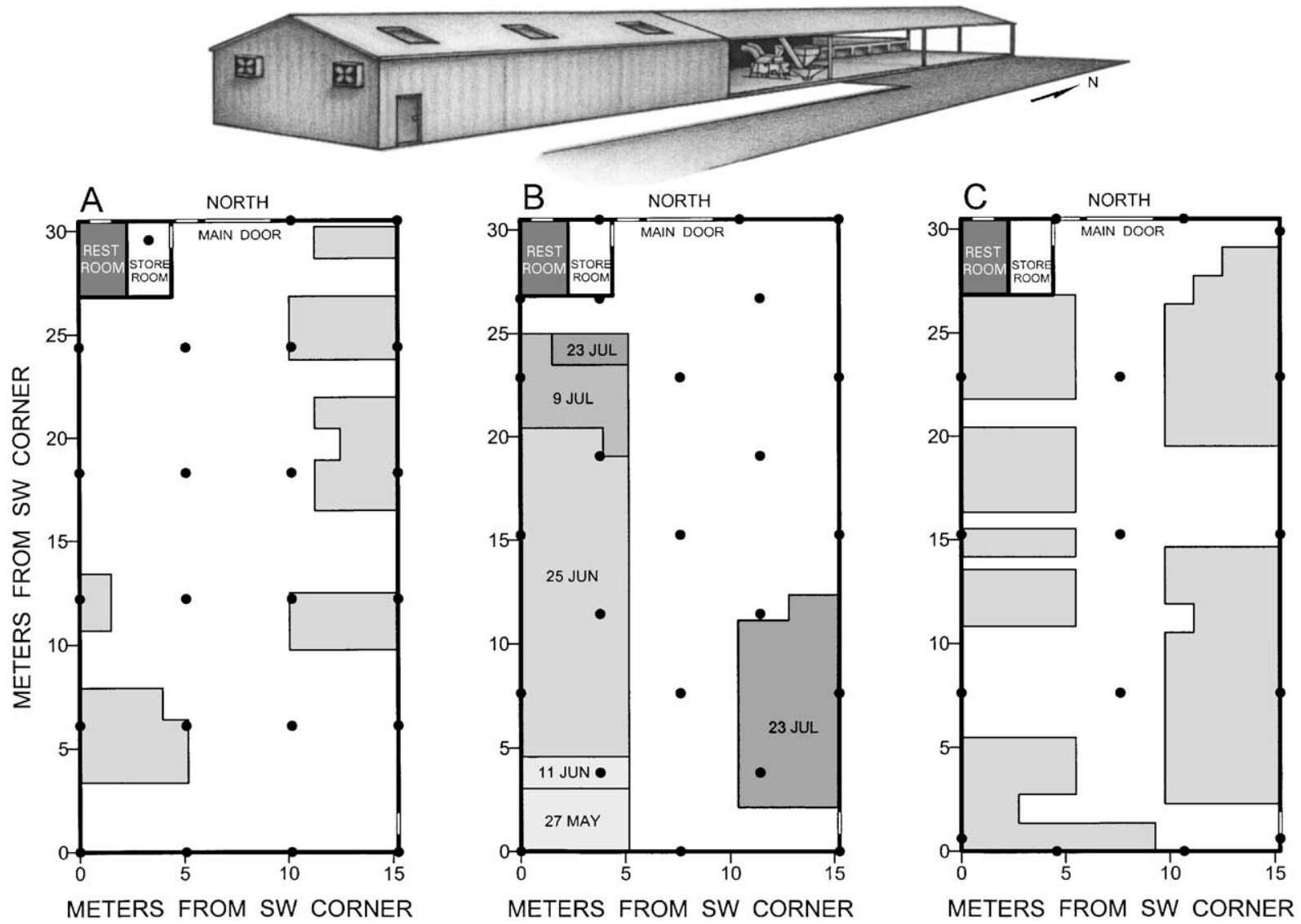

Fig. 1. Botanicals warehouse at Mascotte, Florida. (A)-(C) Floor plans of warehouse showing trap locations (dots) and positions of stacked bags (gray shading). (A) April 1998. (B) May-July 1998. (C) February 1999. 
thoroughly by pressure washing with water and chlorine bleach each time it was emptied, which occurred regularly between crops of saw palmetto and passion-flower, but the area behind the plywood had remained untouched until August 1998, when the warehouse was cleaned prior to storing the 1998 harvest of saw palmetto. At that time, the plywood sheets were removed and the space behind them was cleaned. Then, before they were replaced, about $0.3 \mathrm{~m}$ was removed from the bottom of each sheet, leaving an opening at the floor-wall junction to facilitate future cleaning.

The dried and bagged commodities were stacked, usually six bags high, on wooden pallets, and the pallets were in turn stacked one on top of the other. In April 1998, when our study began, most of the 1997 crop of saw palmetto had been shipped. The remaining stacks, which included the older berries that had been purchased, occupied relatively little of the available floor space (Fig. 1A). By the end of May, all of the berries had been shipped, the warehouse had been cleaned, and storage of passion-flower had begun. The passion-flower came in over a period of about 2 months, and during this period the stacked bags occupied progressively more floor space (Fig 1B). Shipment of passion-flower began in August and was completed by the end of the month. By October, the saw palmetto harvest was over, and the crop was in storage. Most of the floor space was occupied by stacked bags, which at some points reached above the side walls. As the berries were shipped and the stacks diminished, the stacks were rearranged frequently. Fig. 1C shows the arrangement in February 1999.

\subsection{Trapping}

We monitored insect populations in the warehouse intermittently between April 1998 and May 1999. Moths were monitored with pheromone-baited sticky traps (SP-Locator traps with SP Minimoth pheromone dispensers, AgriSense-BCS Ltd., Pontypridd, Mid Glamorgan, UK). Beetles were monitored with pitfall traps (FLITeTRAK M $^{2}$, TRÉCÉ Inc., Salinas, California) baited with confused flour beetle/red flour beetle and cigarette beetle pheromone lures, and a food attractant oil provided with the traps. Trap locations were specified in rectangular coordinates with the origin at the southwest corner of the warehouse. The number and configuration of trap locations (Fig. 1A-C), and the frequency of trap inspection (Table 1) varied. The spacing between traps was always $>4 \mathrm{~m}$, the measured active space of the SP-Locator Trap (Mankin et al., 1999). There was one moth trap and one beetle trap at each location. When trap locations were not occupied by commodity, moth traps were placed $1.2 \mathrm{~m}$ above the floor, attached by means of Velcro either to the walls of the warehouse or to the tops of wooden stakes supported by stands on the floor, and beetle traps were placed on the floor immediately below them. Otherwise, moth traps were placed on top of the stacked bags or attached to walls or steel beams slightly above the stacks, and beetle traps were placed on top of the stacks and as near as possible to the moth traps. Placement of traps under these circumstances was necessarily imprecise, but we estimated that all were within $<1 \mathrm{~m}$ of their designated coordinates. The stacks ranged in height from slightly over $1 \mathrm{~m}$ to about $4.5 \mathrm{~m}$, and trap height varied accordingly.

\subsection{Species composition of the pest population}

Observations of trap catch were grouped by time period and warehouse contents as follows: Spring 1998 (Serenoa), Spring 1998 (Empty), Summer 1998 (Passiflora), and Fall-Spring 1998-99 
(Serenoa) (Table 1). The numbers of insects trapped were summarized in three different ways to express different aspects of the infestation. The species composition of the pest population during each of the periods was determined by calculating the abundance of each pest species relative to the total pest population. Predators and parasitoids were excluded in making these calculations. Relative abundance (total number of a given species/total number of insects) was expressed as a percentage.

\subsection{Variation in rates of capture with time and commodity}

Temporal variation (or variation with commodity) of insect populations was examined using numbers captured per unit trapping effort during each trapping run (Table 1). Trapping effort was expressed as trap days (number of traps $\times$ number of days deployed) and was corrected for lost traps. The total numbers of moths, beetles, or members of individual species captured during each trapping run were divided by the appropriate corrected trapping effort to obtain the rate of capture (insects per trap day). In plotting temporal variation of numbers captured, the midpoint of each trapping run was used as the time $(x)$-coordinate.

\subsection{Spatial distribution of populations}

To determine the spatial distribution of various species, or groups of species, at the time of each trapping run, the $x$ - and $y$-coordinate of the trap positions and the corresponding numbers of insects captured were entered in Surfer 7 (Golden Software, 1999) for contour analysis (Arbogast et al., 1998; Brenner et al., 1998). This software posts observed trap catch to the appropriate

Table 1

Trapping schedule and trapping effort applied to moths or beetles in a botanicals warehouse at Mascotte, Florida

\begin{tabular}{|c|c|c|c|c|c|c|}
\hline \multirow{2}{*}{$\begin{array}{l}\text { Season (warehouse } \\
\text { contents) }\end{array}$} & \multirow[t]{2}{*}{ Trapping dates } & \multicolumn{5}{|l|}{ Trapping } \\
\hline & & $\begin{array}{l}\text { Number } \\
\text { of trap } \\
\text { locations }\end{array}$ & $\begin{array}{l}\text { Frequency } \\
\text { of trapping } \\
\text { runs }^{\mathrm{a}}\end{array}$ & $\begin{array}{l}\text { Number of } \\
\text { trapping } \\
\text { runs }\end{array}$ & $\begin{array}{l}\text { Duration } \\
\text { of each } \\
\text { trapping } \\
\text { run (days) }\end{array}$ & $\begin{array}{l}\text { Trapping } \\
\text { effort }^{\mathrm{b}} \\
(\text { traps } \times \text { days })\end{array}$ \\
\hline Spring 1998 (Serenoa) & 13-17 Apr 1998 & 23 & - & 1 & 4 & 92 \\
\hline Spring 1998 (Empty) & 15-19 May 1998 & 23 & - & 1 & 4 & 92 \\
\hline Summer 1998 (Passiflora) & 27 May-23 July 1998 & 24 & Biweekly & 4 & 14 & $1344^{\mathrm{c}}$ \\
\hline \multirow[t]{2}{*}{ Fall-Spring 1998-99 (Serenoa) } & 30 Oct-6 Nov 1998 & 23 & - & 1 & 7 & $161^{\mathrm{d}}$ \\
\hline & 22 Feb-24 May 1999 & 16 & Monthly & 4 & 4 & 256 \\
\hline Total & & & & & & $1945^{\mathrm{e}}$ \\
\hline
\end{tabular}

${ }^{\text {a }}$ Trapping run refers to the period of time between setting out traps and counting the insects captured. When the frequency of trapping runs was continual, old traps were immediately replaced with new ones after counts are made. When runs were monthly, traps were deployed for only 4 days out of each month.

${ }^{\mathrm{b}}$ Not corrected for traps lost in some trapping runs.

${ }^{\mathrm{c}}$ Corrected trapping effort: 1330 (moths) and 1316 (beetles) trap days.

${ }^{\mathrm{d}}$ Corrected trapping effort: 154 (moths) and 161 (beetles) trap days.

${ }^{\mathrm{e}}$ Corrected trapping effort: 1924 (moths) and 1917 (beetles) trap days. 
coordinates on a floor plan of the warehouse, which has been entered as a base map, and then creates a denser grid of trap catch values by interpolation, using one of several algorithms. We used radial basis functions (with the multiquadric function), which produces good representation of most small data sets ( $<250$ observations) (Golden Software, 1999).

\subsection{Berlese samples}

We examined debris, from the cleaning operations, that covered large areas of ground around the warehouse to determine if it contained stored-product insects. Two samples of the debris (about 1.11 each) were taken on 9 February 1999, one each from the east side and the west side of the warehouse. Each sample was divided into two equal parts, and insects were extracted from the divided samples with Berlese funnels using $40 \mathrm{~W}$ incandescent bulbs. The extraction period was 8 days.

\section{Results and discussion}

\subsection{Insect fauna of the warehouse}

Most of the insects found in the warehouse (Table 2) were species commonly associated with stored products or storage structures, but the elaterid Conoderes aversus (LeConte) was certainly an accidental invader. The carabid Tetragonoderus intersectus (Germar) may also have been accidental, although Hinton (1945) noted a few other carabid species that are regularly associated with stored products or found in storage structures. These species are either carnivorous or phytophagous and carnivorous, but are of little importance either as storage pests or as natural enemies of storage pests. Many Staphylinidae occur in stored products as predators of storage pests (Hinton, 1945).

\subsection{Species composition of the pest population}

Cadra cautella (Walker) and Lasioderma serricorne (F.) were the most abundant insects overall (Table 2), and one or the other was the dominant species throughout the study period (Fig. 2). Cadra cautella was dominant when the warehouse contained saw palmetto, and L. serricorne when it contained passion-flower. In the spring of 1998, the warehouse contained the last of the 1997 saw palmetto crop and the remainder of the older berries purchased from another company. Cadra cautella was clearly dominant, but L. serricorne, Plodia interpunctella (Hübner), and Oryzaephilus mercator (Fauvel) also comprised large portions of the trap catch. A few Tribolium castaneum (Herbst) were trapped, as well as small numbers of Ahasverus advena (Waltl) and Typhaea stercorea (L.). After the last of the berries were shipped and the warehouse was cleaned, C. cautella and $L$. serricorne together made up about $80 \%$ of the residual insects trapped. The remainder consisted of Ahasverus rectus (LeConte), T. castaneum, O. mercator, and P. interpunctella. During the summer of 1998, when the warehouse contained passion-flower, L. serricorne was dominant, followed in relative abundance by $C$. cautella and $T$. stercorea. Several other species were trapped in relatively small numbers as indicated in Fig. 2. The "Other" category, which comprised 3\% of the trap catch, included Corticaria sp., O. mercator, A. advena, Blapstinus fortis (LeConte), Anthicus floralis (L.), 
Table 2

Insect species found by trapping in a botanicals warehouse at Mascotte in North-Central Florida ${ }^{a}$

\begin{tabular}{|c|c|}
\hline Taxon & Number trapped ${ }^{b}$ \\
\hline \multicolumn{2}{|l|}{ Hemiptera } \\
\hline \multicolumn{2}{|l|}{ Anthocoridae } \\
\hline Xylocoris galactinus (Fieber) & 20 \\
\hline \multicolumn{2}{|l|}{ Coleoptera } \\
\hline \multicolumn{2}{|l|}{ Carabidae } \\
\hline Tetragonoderus intersectus (Germar) & 2 \\
\hline \multicolumn{2}{|l|}{ Staphylinidae } \\
\hline Lobrathium sp.,? ventralis (LeConte) ${ }^{\mathrm{c}}$ & 1 \\
\hline Lepitacnus pallidulus (Gyllenhall) & 1 \\
\hline Oligota parva (Kraatz) & 1 \\
\hline Unidentified & 1 \\
\hline \multicolumn{2}{|l|}{ Elateridae } \\
\hline Conoderes aversus (LeConte) & 4 \\
\hline \multicolumn{2}{|l|}{ Anobiidae } \\
\hline Lasioderma serricorne (F.) & 1411 \\
\hline Stegobium paniceum (L.) & 1 \\
\hline \multicolumn{2}{|l|}{ Nitidulidae } \\
\hline Carpophilus hemipterus (L.) & 11 \\
\hline Stelidota coenosa (Erichson) & 1 \\
\hline \multicolumn{2}{|l|}{ Silvanidae } \\
\hline Ahasverus advena (Waltl) & 12 \\
\hline Ahasverus rectus (LeConte) & 16 \\
\hline Oryzaephilus mercator (Fauvel) & 350 \\
\hline \multicolumn{2}{|l|}{ Laemophloeidae } \\
\hline Cryptolestes ferrugineus (Stephens) & 2 \\
\hline Cryptolestes pusillus (Schönherr) & 1 \\
\hline \multicolumn{2}{|l|}{ Languriidae } \\
\hline Cryptophilus integer (Heer) & 35 \\
\hline \multicolumn{2}{|l|}{ Lathridiidae } \\
\hline Corticaria sp. & 11 \\
\hline \multicolumn{2}{|l|}{ Tenebrionidae } \\
\hline Alphitobius diaperinus (Panzer) & 2 \\
\hline Blapstinus fortis (LeConte) & 8 \\
\hline Tribolium castaneum (Herbst) & 113 \\
\hline \multicolumn{2}{|l|}{ Mycetophagidae } \\
\hline Typhaea stercorea (L.) & 299 \\
\hline \multicolumn{2}{|l|}{ Anthicidae } \\
\hline Anthicus floralis (L.) & 5 \\
\hline \multicolumn{2}{|l|}{ Bruchidae } \\
\hline Caryedon serratus (Olivier) & 2 \\
\hline \multicolumn{2}{|l|}{ Hymenoptera } \\
\hline \multicolumn{2}{|l|}{ Braconidae } \\
\hline Habrobracon hebetor (Say) & 5 \\
\hline \multicolumn{2}{|l|}{ Pteromalidae } \\
\hline Anisopteromalus calandrae (Howard) & 7 \\
\hline \multicolumn{2}{|l|}{ Bethylidae } \\
\hline Plastanoxus chittendenii (Ashmead) & 1 \\
\hline
\end{tabular}


Table 2 (continued)

\begin{tabular}{|c|c|}
\hline Taxon & Number trapped ${ }^{b}$ \\
\hline Cephalonomia waterstoni (Gahan) & 3 \\
\hline \multicolumn{2}{|l|}{ Lepidoptera } \\
\hline \multicolumn{2}{|l|}{ Pyralidae } \\
\hline Cadra cautella (Walker) & 1435 \\
\hline Plodia interpunctella (Hübner) & 159 \\
\hline
\end{tabular}

Caryedon serratus (Olivier), Cryptolestes ferrugineus (Stephens), Cryptolestes pusillus (Schönherr), C. aversus, T. intersectus, and staphylinids. Cadra cautella was again dominant from fall 1998spring 1999, when the warehouse contained the 1998 crop of saw palmetto. Lasioderma serricorne was second in abundance, followed by $O$. mercator. Several additional species were trapped in relatively small numbers as indicated in Fig. 2. "Other" insects, which together made up only 1\% of the trap catch, included A. advena, A. rectus, Corticaria sp., Stegobium paniceum (L.), C. ferrugineus, $P$. interpunctella, and staphylinids.

\subsection{Variation in rates of capture with time and commodity}

Temporal variation in rates of capture for the six most abundant species (Fig. 3) may reflect seasonal changes in temperature, but they also suggest differences in ability to infest saw palmetto and passion-flower. Winter at the study site was mild, but temperatures did become low enough to limit insect activity. Monthly mean temperatures between December and March were $<20^{\circ} \mathrm{C}$ at Clermont $7 \mathrm{~S}$, a weather station $16 \mathrm{~km}$ away. Mean monthly minima were $<15^{\circ} \mathrm{C}$, and mean monthly maxima reached only about $24^{\circ} \mathrm{C}$ (National Climatic Data Center, NOAA). Although the interior of the warehouse would have been warmer than this, especially on sunny days, it would still have been cool enough at times to reduce insect activity. Nevertheless, rates of capture were higher for some species during cool months when the warehouse contained saw palmetto than during warm months when it contained passion-flower. This suggests that some of the observed differences in trap catch may best be attributed to differences in suitability of the two commodities as hosts.

There are apparently substantial differences among species in ability to infest saw palmetto, but overall it seems to be a much better host than passion-flower. Cadra cautella was by far the most successful on saw palmetto and achieved the highest population levels (assuming rates of capture reflect population levels) among the six species. Lasioderma serricorne, O. mercator, $P$. interpunctella, and $T$. castaneum achieved progressively lower population levels, and $T$. stercorea was detected on saw palmetto only in the autumn of 1998. Dried passion-flower is apparently a very poor host, but it became infested, nevertheless, especially by L. serricorne. Rates of capture during storage of passion-flower were $<1.0$ per day for all species and $<0.5$ per day for all species except $L$. serricorne and $T$. stercorea. 


\section{SPRING 1998 (SERENOA) \\ TOTAL INSECTS: 960}

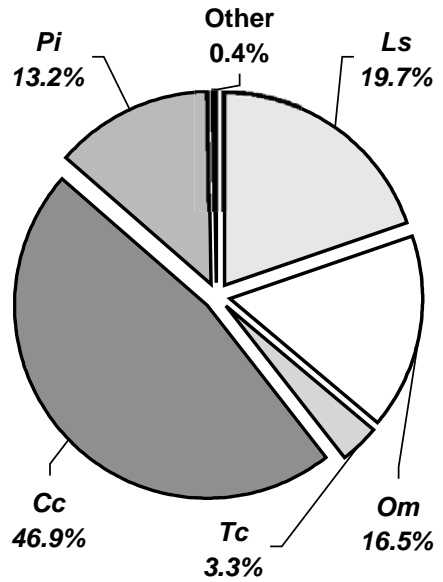

SUMMER 1998

(PASSIFLORA)

TOTAL INSECTS: 1646

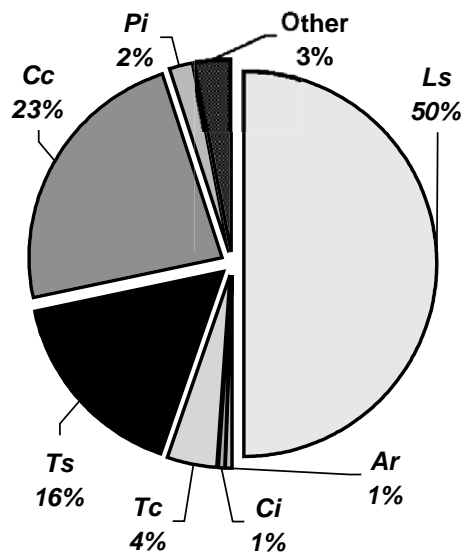

\section{SPRING 1998 (EMPTY)}

TOTAL INSECTS: 51

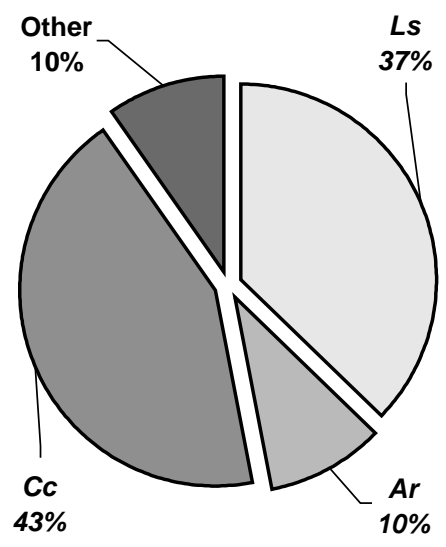

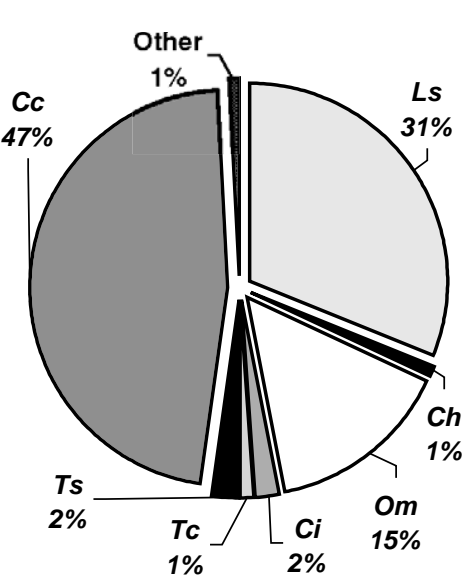

Fig. 2. Changes in the contents of a botanicals warehouse and in the species composition (relative abundance) of its insect pest populations. The total trap catch is given for each period to show the basis of the percentage, but, except for the first two periods, trap catches for different periods are not comparable because they represent different trapping efforts (Table 1). Abbreviations used for species are as follows: Ahasverus rectus (Ar), Cadra cautella (Cc), Cryptophilus integer (Ci), Carpophilus hemipterus (Ch), Lasioderma serricorne (Ls), Oryzaephilus mercator (Om), Plodia interpunctella $(P i)$, Tribolium castaneum $(T c)$, and Typhaea stercorea $(T s)$.

\subsection{Spatial distribution of populations}

The spatial distribution of the pest populations (trap catch) varied with species and time (Figs. 4-6). In April 1998, P. interpunctella was strongly associated with stacks of older saw 

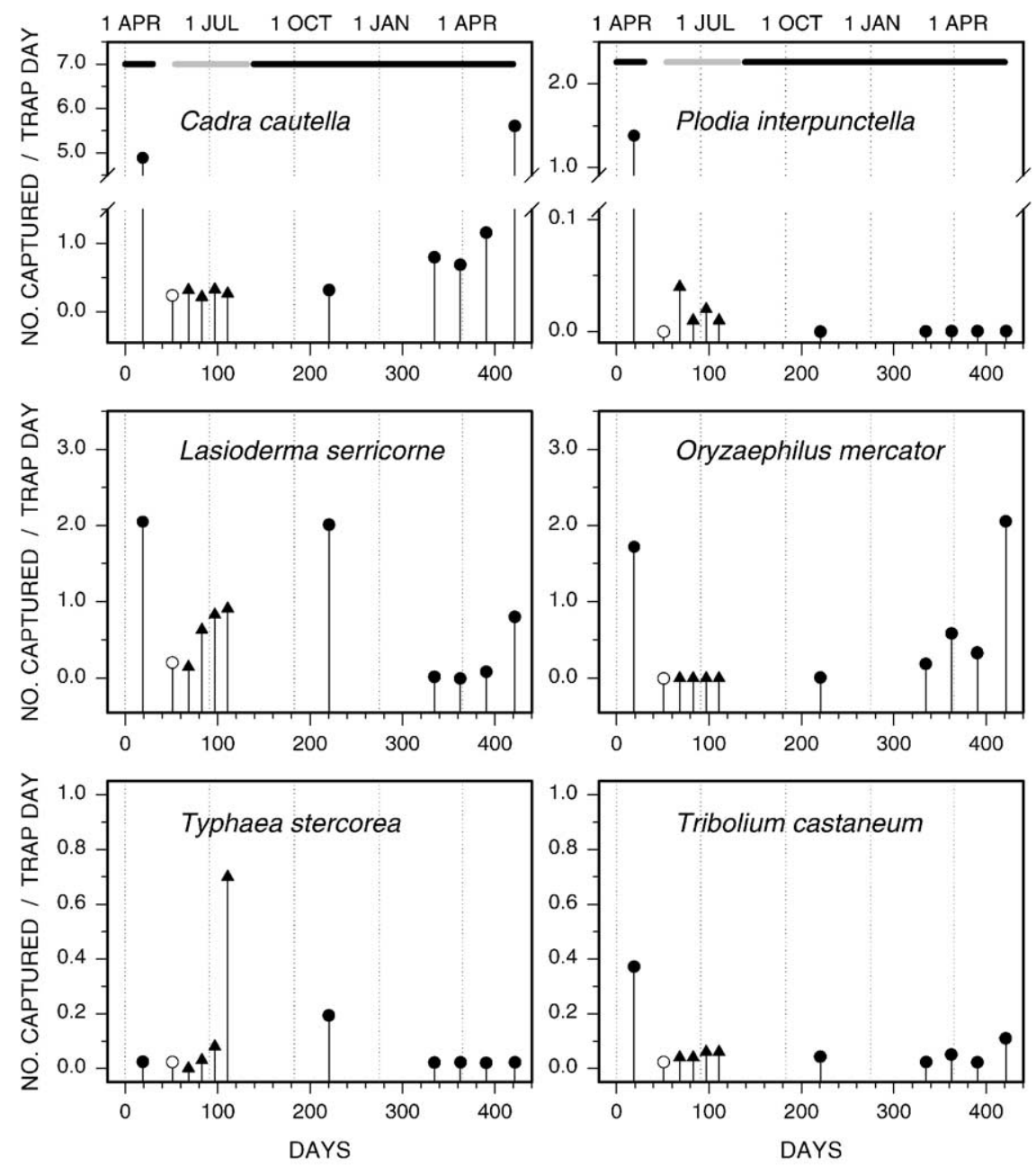

\section{- SERENOA}

○ EMPTY

$\triangle$ PASSIFLORA

Fig. 3. Rates of capture for individual trapping runs of the six most abundant insect pests in a botanicals warehouse. Days $=$ number of days elapsed since the beginning of the first trapping run on 13 April 1998. The horizontal line on each of the two upper graphs represents warehouse contents (black=saw palmetto, gray=passion-flower, gap $=$ empty).

palmetto berries on the east side of the warehouse (Fig. 4A), as were the beetles as a group (Fig. 4B). In May 1998, when the warehouse was empty and had been cleaned, trapping detected residual populations of beetles (Fig. 4C) and moths along the walls and in corners. In July 1998, during storage of passion-flower, T. stercorea was distributed throughout much of the warehouse (Fig. 4D). The largest numbers were detected just north of the stacks on the east wall. In early November 1998, T. stercorea was concentrated in a large center among the stacks on the west wall (Fig. 4E). In general, C. cautella was distributed throughout the warehouse with concentrations at 

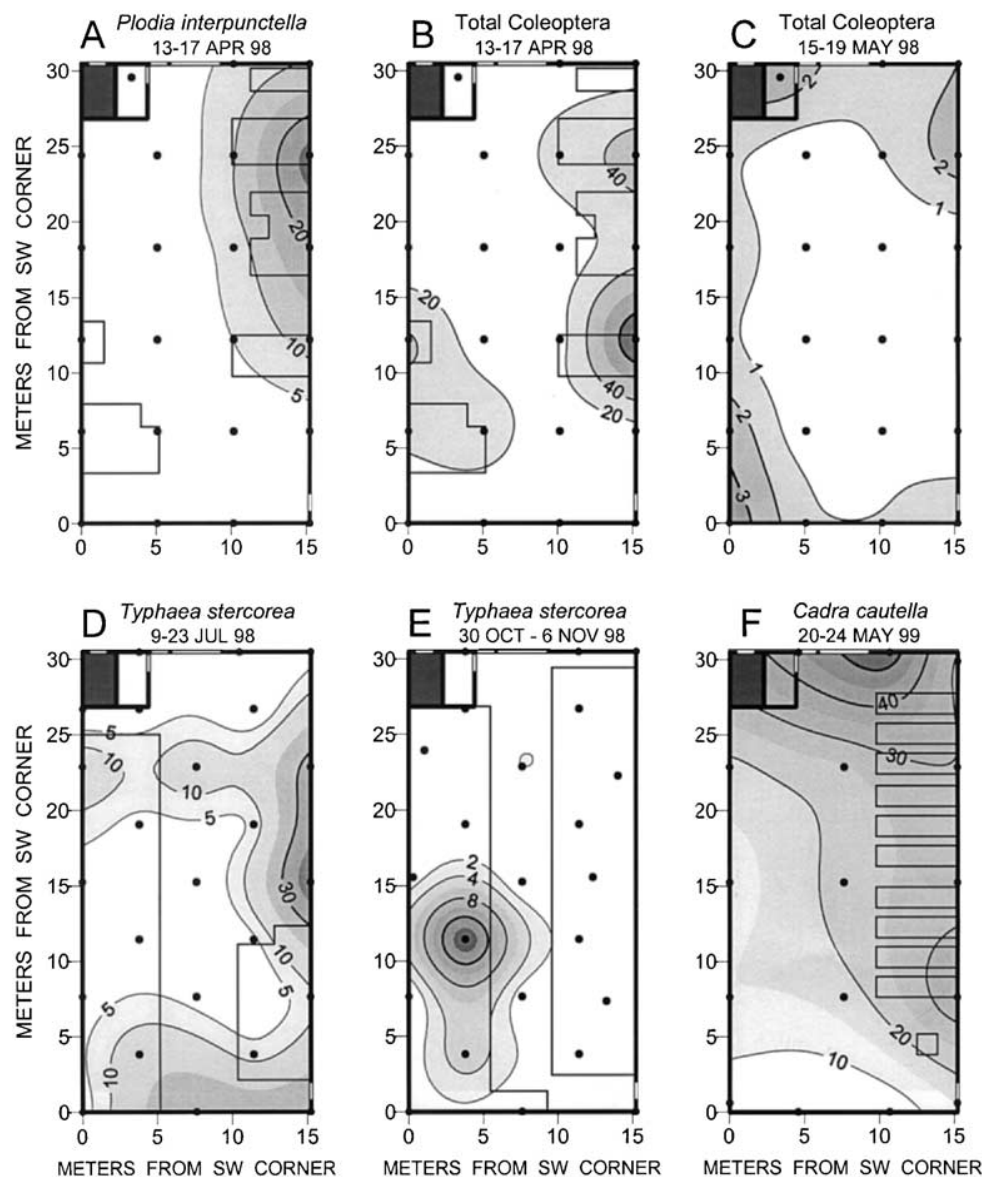

Fig. 4. Spatial distribution of insect populations in a botanicals warehouse as represented by trap catch. The warehouse contained either saw palmetto (A, B, E, F) or passion-flower (D), or was empty (C). Trap locations are indicated by dots and locations of stacked bags by the rectangular outlines. Contours represent numbers captured during the individual trapping runs indicated.

various points. In the example illustrated (Fig. 4F), the largest concentration occurred on the north wall near the main door.

Successive spatial maps for L. serricorne (Fig. 5) and O. mercator (Fig. 6) illustrate temporal change in the distribution of individual species. Trap catch of L. serricorne during April 1998 (Fig. 5A) indicated infestation of all stacks with the heaviest concentration in stacks on the west side of the warehouse. This species survived the cleanup that followed shipment of the saw palmetto berries, probably as residual populations between the walls and the plywood, or outside the warehouse. It was detected in the empty warehouse in May 1998 (Fig. 2), when it occurred with other beetles along the walls and in corners (Fig. 4C). When the first of the passion-flower crop was stored near the end of May, L. serricorne appeared in the southwest corner of the warehouse in association with the commodity, but greater numbers were trapped in the northeast corner, which was empty (Fig. 5B). In late June, the largest numbers were trapped along the north 

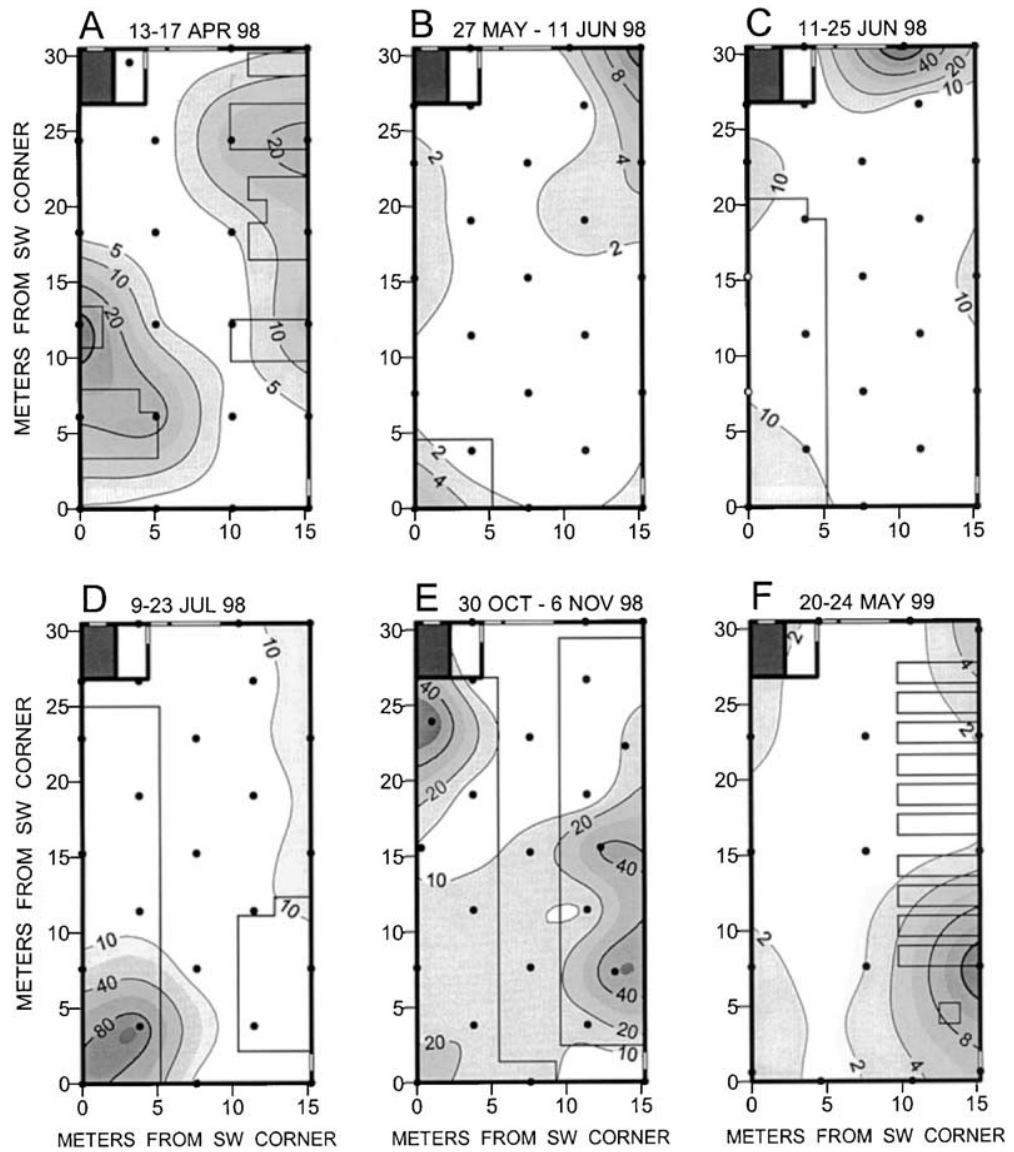

Fig. 5. Spatial distribution of Lasioderma serricorne in a botanicals warehouse as represented by trap catch. The warehouse contained either saw palmetto (A, E, F) or passion-flower (B, C, D). Trap locations are indicated by dots and locations of stacked bags by the rectangular outlines. Contours represent numbers captured during the individual trapping runs indicated.

wall near the main door (Fig. 5C), but significant numbers were also picked up in the southwest corner and in spots along the east and west walls. By late July 1998, the concentration near the main door was gone, and a heavy concentration had developed in the southwest corner (Fig. 5D). Significant numbers were also found along the east wall, north of the stacks on that side of the warehouse. Lasioderma serricorne appeared again in early November 1998, just after the last of the 1998 saw palmetto crop had been placed in the warehouse (Fig. 5E). It occurred in the stacks with concentrations in spots on the east and west walls. By May 1999, most of the saw palmetto had been shipped and the stacks had been extensively rearranged (Fig. 5F). Lower numbers of L. serricorne were trapped, and the largest concentration occurred near a stack on the east wall.

Removal and rearrangement of commodity stacks was almost certainly a major cause of the observed changes in spatial distribution. This hypothesis is well supported by changes in the distribution of $O$. mercator during storage of the 1998 saw palmetto crop (Fig. 6). In February 

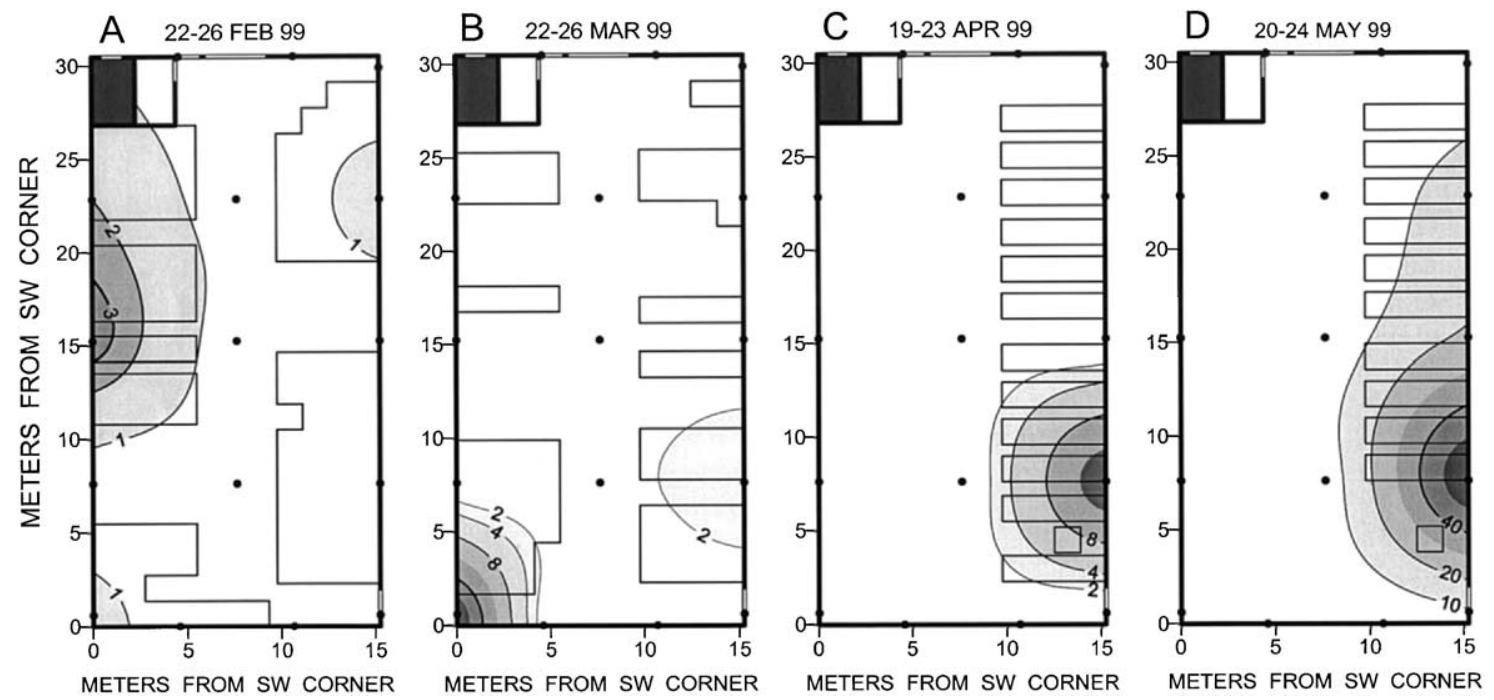

Fig. 6. Changes in the spatial distribution of Oryzaephilus mercator in a botanicals warehouse during storage of saw palmetto. Trap locations are indicated by dots and locations of stacked bags by the rectangular outlines. Contours represent numbers captured during the individual trapping runs indicated.

1999, the few captures of this species occurred mostly near the midpoint of the west wall (Fig. 6A). By March, a substantial amount of the commodity had been shipped and the stacks had been rearranged. Most $O$. mercator were then captured in the southwest corner, but some were also captured at a point along the east wall (Fig. 6B). By April, more commodity had been shipped and the remaining bags were arranged in a row of stacks along the east wall. This area now became the focus of infestation (Fig. 6C). Two of the stacks had been removed by May, but the rest remained. The infestation remained centered at the same point but had intensified and spread (Fig. 6D).

\subsection{Berlese samples of saw palmetto debris}

The Berlese samples yielded a number of stored-product beetles, including two O. mercator, three Carpophilus of the dimidiatus (Fabricius) group (Nitidulidae) (Connell, 1991), two Myrmechixenus lathridiodes Crotch (Colydiidae), and one A. rectus. In addition, the samples yielded various other beetles, including 16 Staphylinidae [five Lepitacnus pallidulus (Gyllenhal), three Oligata parva Kaatz, three Phacophallus tricolor (Kraatz), and five unidentified], 14 Ptiliidae, two Nitidulidae, and two Histeridae. The number of stored-product beetles recovered from such a small sample is sufficient to implicate the saw palmetto debris as a source of infestation.

\section{Conclusions}

Our study showed that $C$. cautella and L. serricorne can be major pests of stored saw palmetto berries. Oryzaephilus mercator and $P$. interpunctella are less important, but still can be serious 
pests. Tribolium castaneum is probably a minor pest, and T. stercorea seems barely capable of infesting saw palmetto. Dried passion-flower is a less suitable host and thus less vulnerable to infestation than saw palmetto. Yet, L. serricorne, C. cautella, P. interpunctella, T. stercorea, and $T$. castaneum appear capable of infesting passion-flower, and at least L. serricorne can be a major pest.

The problem created in stored botanicals by storage insects is often one of contamination. Shipments delivered with live insects may be rejected, or the customer may demand a reduced price. Some botanicals, however, can be seriously damaged by insects. For example, the coffee bean weevil, Araecerus fasciculatus (De Geer) (Anthribidae) is capable of severely damaging stored ginseng roots (Arbogast, personal observation). The present study revealed a number of measures that could be taken to mitigate the problem.

First, it is essential that the warehouse be systematically monitored for insects. Moths were being monitored with pheromone-baited sticky traps when we first visited the study site, but there was no monitoring for beetles. The moth traps gave an indication of overall population levels, but there was no way to locate centers of infestation. A combination of trapping and spatial analysis could be used to precisely target foci of infestation and eliminate them. Second, debris from cleaning operations should be removed from the storage site to deny insect pests breeding areas outside the warehouse. The warehouse we studied has now been closed and the operation moved to a location nearer the major source of saw palmetto. At the new location, all debris from cleaning saw palmetto berries is shipped out to be used as mulch. Third, everything possible should be done to facilitate warehouse sanitation, as for example modifications that prevent debris from accumulating in inaccessible areas. Finally, fumigation or other means will occasionally be needed to eliminate foci of infestation when they are located. The only control measure exercised at the original site was thorough cleaning of the warehouse between crops. At the current location, fumigation with phosphine under a tarpaulin has been used to treat infested stacks. At another warehouse, in which refrigerated storage was available, low temperature was used successfully to eliminate the infestation in ginseng already mentioned.

Measures such as these should help in managing insect infestation of stored botanicals, but much more could be done in adapting current technology for stored-product protection to the special needs of the botanicals industry.

\section{Acknowledgements}

We are indebted to the management of Wilcox Natural Products and especially to Paul Cowan, manager of the Mascotte warehouse, for making their facilities available and for their cooperation in the research. Betty Weaver and Shahpar Chini assisted with many aspects of the study, and we appreciate their untiring efforts in setting up tests, making observations, and tabulating data. Shahpar Chini also provided skillful assistance in analyzing data and preparing figures, and offered many valuable suggestions. We thank Dee Arbogast for assistance in setting up the test to monitor the empty warehouse in May 1998. We are indebted to the systematists who identified and provided information on some of the insects captured: M.C. Thomas (Division of Plant Industry, Florida Department of Agriculture and Consumer Services, Gainesville) identified specimens of various Coleoptera and J.H. Frank (Department of Entomology and Nematology, 
University of Florida, Gainesville) identified specimens of Staphlylinidae. Finally, we would like to express our appreciation to F.H. Arthur and R.L. Meagher for their critical review of an earlier version of the manuscript and for their helpful suggestions. Research reported in this paper was supported in part by funds from Pollution Prevention Project No. 1053, Strategic Environmental Research and Development Program (SERDP), and from EPA-USDA/ARS Interagency Agreement No. DW12937600-01-0. Both of these projects were led by Rick Brenner, and we are grateful for his cooperation and assistance.

\section{References}

Arbogast, R.T., Weaver, D.K., Kendra, P.E., Brenner, R.J., 1998. Implications of spatial distribution of insect populations in storage ecosystems. Environmental Entomology 27, 202-216.

Basak, P.K., 1991. New records and seasonality of beetles infesting stored herbal drugs. Geobios New Reports 10, $38-41$.

Bennett, B.C., Hicklin, J.R., 1998. Uses of saw palmetto (Serenoa repens, Arecaceae) in Florida. Economic Botany 52 , 381-393.

Brenner, R.J., Focks, D.A., Arbogast, R.T., Weaver, D.K., Shuman, D., 1998. Practical use of spatial analysis in precision targeting for integrated pest management. American Entomologist 44, 79-101.

Chmielewski, W., Golebiowska, Z., 1971. Wystepowanie roztoczy (Acarina) w magazynowanych surowcach zielarskich. The occurrence of acarina in stored herbal raw materials. Prace Naukowe Instytutu Ochrony Roślin 13, 67-86.

Connell, W.A., 1991. Sap beetles (Nitidulidae, Coleoptera). In: Gorhham, J.R., (Ed.), Insect and Mite Pests in Food: An Illustrated Key, Agriculture Handbook No. 655, US Department of Agriculture and US Department of Health and Human Services, Washington, DC, pp. 151-174 and 575-580.

El-Halfawy, M.A., 1977. Entomofauna of dried medical and aromatical plants with a short note on their occurrence and populations. Agricultural Research Review 55, 103-106.

Golden Software, 1999. Surfer 7 User's Guide. Golden Software, Inc., Golden, CO.

Hinton, H.E., 1945. A monograph of the beetles associated with stored products. British Museum (Natural History), London, UK.

Kalinovic, I., Rozman, V., 2000. Infestation of stored medicinal plants and herbal tea by insects and mites. Plant Protection 36, 21-22.

Kamel, A.H., 1958. A preliminary list of insects encountered in stored drugs in Egypt and their control. Agricultural Research Review 36, 94-95.

Li, C., Wu, Q., Ma, C., Lu, W., Qin, Z., Gu, J., 1998. Preliminary investigation of acarid mites in stored traditional Chinese medicinals. Acta Arachnologica Sinica 7, 103-109.

Mankin, R.W., Arbogast, R.T., Kendra, P.E., Weaver, D.K., 1999. Active spaces of pheromone traps for Plodia interpunctella (Lepidoptera: Pyralidae) in enclosed environments. Environmental Entomology 28, 557-565.

McGuire, C.M., 1999. Passiflora incarnata (Passifloraceae): a new fruit crop. Economic Botany 53, 161-176.

Tawfik, M.F.S., Awadallah, K.T., El-Husseini, M.M., Afifi, A.I., 1985. Survey of stored drug insect, mite pests and their associated natural enemies in Egypt. Bulletin Société entomologique d'Égypt 65, 267-274.

Weidner, H., 1973. Insekten als schädlinge an drogen in apotheken und drogerien. Insects as pests of drugs in pharmacies and drug stores. Anzeiger für Schädlingskunde 46, 177-180. 